Pomáhajúce profesie, roč. 4, č. 1, 2021, 49-57

\title{
PERFEKCIONIZMUS, PERMA OPTIMÁLNE PROSPEROVANIE A ČAS STRÁVENÝ NA INSTAGRAME
}

\author{
Laura Filipčíková, Gabriela Šeboková \\ Katedra psychologických vied FSVaZ UKF v Nitre \\ gsebokova@ukf.sk
}

\begin{abstract}
Abstrakt: Ciel'om výskumu bolo overit' mediačný efekt intenzity používania sociálnej siete Instagram vo vzt'ahu medzi perfekcionizmom a jednotlivými PERMA prvkami optimálneho prosperovania vo vynárajúcej sa dospelosti. Taktiež sme si kládli za ciel' overit' vzt'ahy medzi jednotlivými premennými (1. perfekcionizmus a optimálne prosperovanie; 2. perfekcionizmus a čas na Instagrame; 3. čas na Instagrame a optimálne prosperovanie). Na meranie perfekcionizmu sme použili Multidimenzionálny dotazník perfekcionistických kognícií - MPCI-E (Stoeber, Kobori \& Tano, 2010). Čas strávený na Instagrame sme zist'ovali pomocou ukazovatel'a aktivity v aplikácii Instagram. Optimálne prosperovanie sme merali prostredníctvom dotazníka PERMA - Profiler (Butler \& Kern, 2016). Výskumnú vzorku tvorilo 295 študentov vysokých škôl vo veku od 18 do 25 rokov. Z výsledkov vyplynulo, že dimenzia adaptívneho perfekcionizmu Osobné štandardy negatívne predikuje optimálne prosperovanie, zatial' čo dimenzia maladaptívneho perfekcionizmu Obavy z chýb ho predikuje negatívne. Ďalej sme zistili, že žiadna z dimenzií perfekcionizmu významne nepredikuje čas strávený na Instagrame a ani čas na Instagrame významne nepredikuje PERMA prvky optimálneho prosperovania. Z tohto dôvodu čas strávený na Instagrame nemohol byt' považovaný za mediátora vzt'ahu medzi perfekcionizmom a jednotlivými PERMA prvkami optimálneho prosperovania.
\end{abstract}

Kl'účové slová: perfekcionizmus, optimálne prosperovanie, PERMA, čas strávený na Instagrame, vynárajúca sa dospelost'

\section{ÚVOD}

V posledných rokoch sme svedkami toho, že sociálne siete naberajú na popularite a čoraz viac ich využíva väčší počet najmä mladých l'udí, s čoraz väčšou intenzitou. Tento nárast je zjavný predovšetkým pri Instagrame, sociálnej sieti založenej na zdiel'aní fotografií a videí, ktorú celosvetovo využíva 1 miliarda l'udí mesačne (Statista, 2020). Tento rastúci trend využívania Instagramu je zjavný aj v našich končinách. Podl'a Statista (2021) v decembri 2020 bolo na Slovensku 1448700 aktívnych používatel'ov Instagramu, pričom takmer tretinu z nich (31,8\%) tvoria mladí l’udia - vynárajúci sa dospelí. Vynárajúca sadospelost' (Arnett, 2000) je obdobím utvárania svojej identity, pričom prostriedkom na vytváranie a prezentovanie svojho „ja“ môže byt' svojou všestrannost'ou a neobmedzenost'ou práve Instagram.

Celkovo možno konštatovat', že posledné generácie mladých l'udí vnímajú, že ostatní na nich kladú vyššie nároky, že oni kladú vyššie nároky na ostatných a že sú tiež náročnejší sami na seba. Práve toto sú charakteristiky perfekcionizmu, ktoré sú pozorovatel'né aj na Instagrame, kde sa jednotlivec snaží vyzerat' najdokonalejšie, ba čo viac, je to od neho vyžadované,a rovnako to vyžaduje aj on od ostatných. To ho núti k tomu, aby premýšl'al o tom, či je dostatočne dokonalý, alebo sa obával toho, že nebude dostatočne dokonalý. Týmto negatívnym automatickým 
myšlienkam o perfekcionistických témach sa hovorí „perfekcionistické kognície“ (Flett, Hewitt, Blankstein \& Gray, 1998).

Optimálne prosperovanie je pojem vyskytujúci sa najmä v posledných rokoch vo viacerých teóriách zaoberajúcich sa zdravým psychickým fungovaním, teda well-beingom. Charakteristickým znakom týchto prác je, že ich autori pojem well-being zamenili za optimálne prosperovanie. Optimálne prosperovanie je podl'a Seligmana (2011) určované piatimi prvkami, pre ktoré je zaužívaný akronym PERMA: pozitívne emócie (P), zaujatie činnost'ou (E), pozitívne vzt'ahy (R), zmysluplnost' $(\mathrm{M})$, úspešný výkon $(\mathrm{A})$.

V predkladanej štúdii sa zameriavame na vzt’ah medzi perfekcionizmom a optimálnym prosperovaním mladých l'udí, pričom fokusom práce je overenie mediačného modelu, v ktorom je čas na Instagrame koncipovaný ako mediátor. Myslíme si totiž, že zidealizovaná povaha Instagramu u jeho perfekcionistických používatel'ov môže viest' k častejšiemu používaniu Instagramu, čo by mohlo mat' za následok zhoršené optimálne prospievanie u vynárajúcich sa dospelých.

\section{Perfekcionizmus a optimálne prosperovanie}

Zdá sa, že perfekcionizmus vykazuje rôzne vzt’ahy s optimálnym prosperovaním. Konkrétne sa zistilo, že adaptívny perfekcionizmusvedie k podporovaniu optimálneho prosperovania, zatial' čo maladaptívny perfekcionizmus ho zhoršuje (Stoeber \& Corr, 2016). K rovnakému záveru prišli aj Birchová, Riby a McGannová (2019), ktorých výsledky ukázali, že maladaptívny perfekcionizmus negatívne predikoval všetky prvky PERMA. Adaptívny perfekcionizmus naopak pozitívne predikoval takmer všetky PERMA prvky s výnimkou pozitívnych vzt'ahov. Na základe týchto zistení sme predpokladali, že adaptívne dimenzie perfekcionizmu Osobné štandardy a Snaha o dokonalost' budú pozitívne predikovat' PERMA prvky optimálneho prosperovania (H1 a H2), zatial' čo maladaptívna dimenzia perfekcionizmu Obavy z chýb bude PERMA prvky optimálneho prosperovania predikovat' negatívne (H3).

\section{Perfekcionizmus a používanie Instagramu}

Skúmanie vzt'ahu perfekcionismu a používanie sociálnej siete Instagram prinieslo nejednoznačné zistenia. Padoaová, Berle a Robertsová (2018) zistili, že ani adaptívny, ani maladaptívny perfekcionizmus nebol významne spojený s frekvenciou používania sociálnej siete Instagram u matiek. Turnerová a Lefevreová (2017) naopak zistili, že častejšie používanie Instagramu u žien vedie k vyššej tendencii k orthorexii nervose (posadnutosti zdravým stravovaním), ktorá vykazuje črty perfekcionizmu, pričom pri žiadnej inej sociálnej sieti sa táto asociácia nepotvrdila. A napokon Perloff (2014) poukázal na tendenciu mladých perfekcionistických žien využívat’ sociálne siete na overenie si svojho fyzického vzhl'adu, čo vedie k častejšiemu využívaniu a porovnávaniu sa na Instagrame. Je zrejmé, že mladí l’udia s perfekcionistickými charakteristikami majú tendenciu porovnávat’ sa s ostatnými používatel'mi na Instagrame (Padoaová, Berle \& Roberts, 2018), čo by podl'a nášho predpokladu mohlo viest' k vysokej frekvencii času na tejto sociálnej sieti. Preto sme predpokladali, že dimenzie perfekcionizmu (Osobné štandardy, Snaha o dokonalost', Obavy z chýb) budú pozitívne predikovat' čas strávený na sociálnej sieti Instagram (H4-H6).

\section{Používanie Instagramu a optimálne prosperovanie}

Z hl'adiska frekvencie používania Instagramu uvádzame rozsiahlu štúdiu Lupovej, Trubovej a Rosenthalovej (2015), ktorej výsledky ukázali, že častejšie používanie Instagramu má za následok depresívne príznaky, ktoré pohodu značne narušujú. Ďalej Sherlocková a Wagstaffová (2019) zistili, že frekvencia používania Instagramu koreluje okrem všeobecnej úzkosti aj s úzkost’ou z fyzického vzhl'adu, depresívnymi príznakmi, zníženou sebaúctou a nespokojnost'ou 
so svojim telom a celkovým vzhl'adom, ktoré sú protipólmi zdravého fungovania. V protiklade k týmto zisteniam však stoja výsledky z už spomenutej štúdie Padoaovej, Berleho a Robertsovej (2018), z ktorých vyplynulo, že frekvencia používania Instagramu nemala žiaden vplyv na depresiu, úzkost' ani stres. $V$ tomto prípade je však dôležité pripomenút', že frekvencia používania Instagramu korelovala s frekvenciou používania Facebooku, ktorá bola v rozličných mierach významne spojená so všetkými troma spomenutými premennými. Na základe uvedených zistení sme predpokladali, že čas strávený na sociálnej sieti Instagram bude negatívne predikovat' PERMA prvky optimálneho prosperovania (H7).

Pokial' je nám známe, doposial' nebola uskutočnená žiadna výskumná štúdia, ktorá by sledovala mediačnú úlohu času stráveného na Instagrame medzi perfekcionizmom a optimálnym prosperovaním mladých l'udí. Preto sme chceli odpovedat' na otázku, či je vzt'ah medzi perfekcionizmom a optimálnym prosperovaním mediovaný časom stráveným na sociálnej sieti Instagram? (VO1)

\section{METÓDY}

\section{Výskumný súbor}

Výskumnú vzorku sme získali pomocou lavínového výberu (metóda snehovej gule). Finálnu vzorku tvorilo 295 študentov vysokých škôl vo veku 18 až 25 rokov (priemerný vek = 21,52, SD = 1,75), pričom z nich bolo 239 žien (81\%) a 56 mužov (19\%).

\section{Metodiky}

Čas strávený na sociálnej sieti Instagram bol presne zist'ovaný pomocou funkcie sledovania aktivity, ktorú ponúka samotná aplikácia.

$\mathrm{Na}$ meranie perfekcionizmu sme využili 15-položkový Multidimenzionálny dotazník perfekcionistických kognícií MPCI-E (Stober, Kobori \& Tanno, 2010), v slovenskej verzii (Kondášová, 2017). Dotazník obsahuje tri dimenzie: Osobné štandardy (adaptívna dimenzia), Snaha o dokonalost' (adaptívna dimenzia) a Obavy z chýb (maladaptívna dimenzia). Položky sú hodnotené na 4-bodovej škále (1 - nikdy, 2 - niekedy, 3 - často, 4 - vždy), pričom posudzované je obdobie za posledný týždeň. Cronbachova alfa dosahovala prijatel'né až dobré hodnoty od 0,71 0,87 .

Optimálne prosperovanie sme merali prostredníctvom 23-položkového dotazníka PERMA-Profiler od Butlerovej a Kernovej (2016), v slovenskej verzii Čerešníka (2016). Dotazník hodnotí optimálne prosperovanie $\mathrm{v}$ posledných troch mesiacoch, a to $\mathrm{v}$ piatich doménach - pozitívne emócie (P), zaujatie činnost'ou (E), pozitívne vzt'ahy $(R)$, zmysluplnost' $(M)$ a úspešný výkon $(A)$. Odpovede uvádzali na 5-stupňovej škále (A - nikdy/vôbec, B - občas/trochu, C - niekedy/stredne, D - dost' často/vel'mi, E - vždy/úplne). Vnútorná konzistencia v našej vzorke dosiahla vysokú vnútornú konzistenciu pre celkové skóre $(\alpha=0,86)$, pri jednotlivých dimenziách boli hodnoty Cronbachovej alfy nižšie, niektoré neuspokojivé: $\alpha=0,84(\mathrm{P}), \alpha=0,39$ (E), $\alpha=0,23(\mathrm{R}), \alpha=0,84(\mathrm{M}), \alpha=0,45$ (A).

\section{Priebeh a realizácia výskumu}

Za účelom zberu dát bola vytvorená batéria testovacích metód, ktorá bola pomocou Google formulára prevedená do online podoby. Takto formátovaný dotazník bol respondentom sprístupnený prostredníctvom aktívneho hypertextového odkazu. Pred realizáciou výskumu boli respondenti informovaní o podmienkach (nutnost' využívania aplikácie Instagram) a etických aspektoch výskumu (dobrovol'nost', anonymita, uvedený kontakt na zodpovedného riešitel'a). 
Dáta boli vyhodnocované pomocou štatistického programu SPSS 26.0. V prvom kroku sme zist'ovali normalitu rozloženia dát a prítomnost' extrémnych hodnôt. Jedna extrémna hodnota (outlier) v premennej Čas na Instagrame bola odstránená. Na overenie hypotéz boli použité jednoduché lineárne regresie, s využitím ENTER analýzy. Ked’že už v tomto kroku sme z našich dát zistili štatistickú nevýznamnost', nemohli sme vykonat' mediáciu, ako sme pôvodne plánovali.

VÝSLEDKY

\section{Perfekcionizmus a PERMA prvky optimálneho prosperovania}

Vtabul'ke 1 uvádzame výsledky lineárnych regresií medzi jednotlivými dimenziami perfekcionizmu a PERMA prvkami optimálneho prosperovania.

Tabul'ka 1 - Vzt'ah medzi jednotlivými dimenziami perfekcionistických kognícií a optimálnym prosperovaním

\begin{tabular}{|c|c|c|c|c|c|c|c|c|c|c|c|c|c|}
\hline & \multirow[b]{2}{*}{$\mathrm{n}$} & \multicolumn{2}{|c|}{$\mathrm{P}$} & \multicolumn{2}{|c|}{$\mathrm{E}$} & \multicolumn{2}{|c|}{$\mathrm{R}$} & \multicolumn{2}{|c|}{ M } & \multicolumn{2}{|c|}{ A } & \multicolumn{2}{|c|}{ PERMA } \\
\hline & & $\beta$ & $\mathrm{p}$ & $\beta$ & $\mathrm{p}$ & $\beta$ & $\mathrm{p}$ & $\beta$ & $\mathrm{P}$ & $\beta$ & $\mathrm{p}$ & $\beta$ & $\mathrm{p}$ \\
\hline OŠ & $\begin{array}{c}29 \\
5\end{array}$ & $\begin{array}{c}, 21 \\
2\end{array}$ & $\begin{array}{c}\mathbf{0 0} \\
0\end{array}$ & $\begin{array}{c}, 25 \\
0\end{array}$ & $\begin{array}{c}, 00 \\
0\end{array}$ & $\begin{array}{c}\mathbf{1 7} \\
\mathbf{0}\end{array}$ & $\begin{array}{c}, 00 \\
3\end{array}$ & $\begin{array}{c}, 36 \\
9\end{array}$ & $\begin{array}{c}, 00 \\
0\end{array}$ & $\begin{array}{c}, 35 \\
8\end{array}$ & $\begin{array}{c}, 00 \\
0\end{array}$ & $\begin{array}{c}, 35 \\
4\end{array}$ & $\begin{array}{c}, 00 \\
0\end{array}$ \\
\hline SOD & $\begin{array}{c}29 \\
5\end{array}$ & $\begin{array}{c}- \\
, 075\end{array}$ & 198 & $\begin{array}{c}, 22 \\
2\end{array}$ & $\begin{array}{c}, 00 \\
0\end{array}$ & ,057 & ,330 & 111 & ,056 & $\begin{array}{c}18 \\
9\end{array}$ & $\begin{array}{c}, 00 \\
1\end{array}$ & 107 & ,068 \\
\hline $\begin{array}{l}\text { OZC } \\
\mathrm{H}\end{array}$ & $\begin{array}{c}29 \\
5\end{array}$ & $\begin{array}{c}- \\
, 37 \\
4\end{array}$ & $\begin{array}{c}, 00 \\
0\end{array}$ & $\begin{array}{c}- \\
, 017\end{array}$ & ,771 & $\begin{array}{c}- \\
, 21 \\
6\end{array}$ & $\begin{array}{c}, 00 \\
0\end{array}$ & $\begin{array}{c}- \\
, 30 \\
5\end{array}$ & $\begin{array}{c}, 00 \\
0\end{array}$ & $\begin{array}{c}- \\
, 17 \\
5\end{array}$ & $\begin{array}{c}, 00 \\
3\end{array}$ & $\begin{array}{c}- \\
, 32 \\
5\end{array}$ & $\begin{array}{c}, 00 \\
0\end{array}$ \\
\hline
\end{tabular}

$\mathrm{n}$ - počet respondentov, $\beta$ - štandardizovaný koeficient, $\mathrm{p}$ - koeficient štatistickej významnosti,

OŠ - Osobné štandardy, SOD - Snaha o dokonalost', OZCH - Obavy z chýb, P - Pozitívne emócie,

E - Zaujatie činnost'ou, R - Pozitívne vzt'ahy, M - Zmysluplnost', A - Úspešný výkon, PERMA celkové optimálne prosperovanie

Z výsledkov vyplýva, že dimenzia Osobných štandardov štatisticky významne $(\mathrm{p}<0,001)$ predikuje všetky PERMA prvky optimálneho prosperovania. Sila vzt'ahov s jednotlivými PERMA prvkami je slabá $(P-\beta=0,212 ; E-\beta=0,250 ; R-\beta=0,170)$ alebo stredne silná $(M-\beta=0,369 ; A-\beta=0,358)$. Stredne silný vzt’ah bol tiež zaznamenaný pri celkovom optimálnom prosperovaní $(\beta=0,354)$. Hypotézu 1 prijímame.

Dimenzia Snaha o dokonalost' významne nepredikuje $(\mathrm{p}>0,05)$ celkové optimálne prosperovanie. Bol však zistený štatisticky významný pozitívny slabý vzt’ah so Zaujatím činnost'ou $(\beta=0,222)$ a Úspešným výkonom $(\beta=0,189)$. S ostatnými PERMA prvkami sa však nepreukázali štatisticky významné vzt'ahy, a preto hypotézu 2 zamietame.

Napokon dimenzia Obavy z chýb štatisticky významne $(\mathrm{p}<0,001)$ negatívne predikuje takmer všetky prvky optimálneho prosperovania, s výnimkou Zaujatia činnost'ou ( $p>0,001)$. Zistené významné štatistické predikcie vykazujú negatívne vzt'ahy slabej $(R-\beta=-0,216$ a $A-\beta=-0,175)$ alebo strednej sily (P - $\beta=-0,374$ a $M-\beta=-0,305)$. Stredne silný negatívny vzt'ah sa preukázal aj $\mathrm{S}$ celkovým optimálnym prosperovaním $(\beta=-0,325)$. Na základe týchto zistení hypotézu 3 zamietame. 


\section{Perfekcionizmus a čas strávený na Instagrame}

V tabul'ke 2 uvádzame výsledky lineárnych regresií medzi jednotlivými dimenziami perfekcionizmu a časom stráveným na sociálnej sieti Instagram.

Výsledky ukázali, že ani jedna z dimenzií perfekcionizmu významne nepredikuje $(p>0,05)$ čas strávený na sociálnej sieti Instagram. Z toho vyplýva, že hypotézu 4, hypotézu 5 a hypotézu 6 zamietame.

Tabul'ka 2 - Vzt'ah medzi jednotlivými dimenziami perfekcionistických kognícií a časom stráveným na Instagrame

\begin{tabular}{lccc}
\hline & & \multicolumn{2}{c}{ Čas na Instagrame } \\
\cline { 2 - 4 } OŠ & $\mathrm{n}$ & $\beta$ & $\mathrm{p}$ \\
SOD & 295 &,- 017 &, 772 \\
OZCH & 295 &,- 024 &, 684 \\
& 295 &,- 110 &, 059 \\
\hline n - počet respondentov, $\beta$ - štandardizovaný koeficient, p - koeficient štatistickej významnosti, OŠ \\
- Osobné štandardy, SOD - Snaha o dokonalost', OZCH - Obavy z chýb
\end{tabular}

\section{Čas strávený na Instagrame a PERMA prvky optimálneho prosperovania}

$\mathrm{V}$ poslednom rade uvádzame $\mathrm{v}$ tabul'ke 3 zistenia vzt'ahov medzi časom stráveným na Instagrame a jednotlivými PERMA prvkami optimálneho prosperovania.

Tabul'ka 3 - Vzt'ah medzi jednotlivými časom stráveným na Instagrame a jednotlivými PERMA prvkami

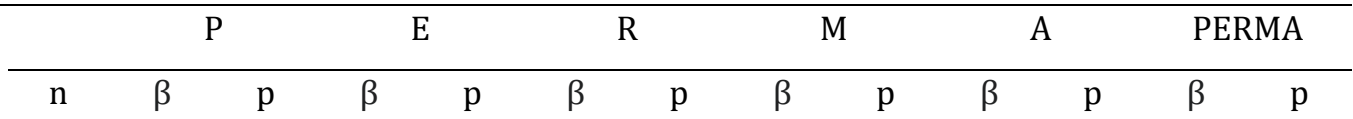

Čas

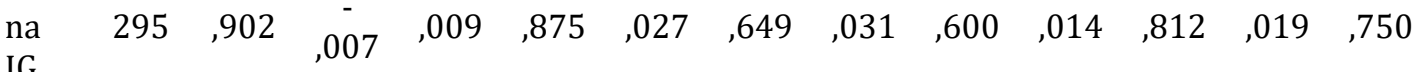

IG

$\mathrm{n}$ - počet respondentov, $\beta$ - štandardizovaný koeficient, $\mathrm{p}$ - koeficient štatistickej významnosti, $\mathrm{P}$ - Pozitívne emócie, E - Zaujatie činnost'ou, R - Pozitívne vzt'ahy, M - Zmysluplnost', A - Úspešný výkon, PERMA - celkové optimálne prosperovanie, IG - Instagram

Tabul'ka 3 ukazuje, že sa nepotvrdil štatisticky významný vzt’ah medzi časom stráveným na Instagrame ani s jedným PERMA prvkom optimálneho prosperovania a rovnako ani s celkovým optimálnym prosperovaním ( $p>0,05)$. Hypotézu 7 zamietame.

\section{DISKUSIA}

Ciel’om nášho výskumu bolo overit' mediačnú úlohu času stráveného na sociálnej sieti Instagram vo vzt'ahu medzi perfekcionizmom a jednotlivými PERMA prvkami optimálneho prosperovania $\mathrm{v}$ období vynárajúcej sa dospelosti. Pre overenie účinku tejto mediácie bolo najskôr potrebné preskúmat' vzt'ahy medzi jednotlivými premennými, ktoré mali byt' súčast'ou nášho mediačného modelu. Ked'že sa čas strávený na Instagrame nepreukázal ako významná predikovaná premenná v kontexte perfekcionizmu a rovnako ani ako významný prediktor optimálneho prosperovania, 
mediačný model nemohol byt’ zrealizovaný. Z vykonaných lineárnych regresií, ktoré sme využili pri zist’ovaní vzt’ahov medzi skúmanými premennými však vyplynulo niekol'ko dôležitých zistení.

\section{Perfekcionizmus a PERMA prvky optimálneho prosperovania}

Azda najzásadnejšie zistenie, v súlade s viacerými predošlými (Stoeber \& Otto, 2006, Stoeber \& Corr, 2016; Birch, Riby \& McGann, 2019), spočíva v rozličnom dopade perfekcionizmu na optimálne prosperovanie $\mathrm{v}$ kontexte odlíšenia medzi adaptívnym a maladaptívnym perfekcionizmom.

Ako sme predpokladali, adaptívna dimenzia perfekcionizmu Osobné štandardy pozitívne predikuje celkové optimálne prosperovanie aj všetky jeho PERMA prvky. Z uvedeného vyplýva, že čím vyššie osobné štandardy si vysokoškoláci na seba kladú a čím viac o nich premýšlajú, tým optimálnejšie budú prosperovat'. Je teda pravdepodobné, že l'udia, ktorí považujú dokonalost' za osobne dôležitú, majú pocit, že ich život je viac naplnený a pozitívnejší. Vytvárajú a udržiavajú si tiež pozitívne vzt'ahy s ostatnými, dokážu sa naplno venovat' dôležitým činnostiam, čo im môže priniest' úspech a pocit zadost'učinenia.

Pokial' však hovoríme o adaptívnej dimenzii Snaha o dokonalost', výsledky sa preukázali ako nejednoznačné. Ukázalo sa, že Snaha o dokonalost' nie je štatisticky významne spojená s celkovým optimálnym prosperovaním, čo je v súlade s výsledkami Molnarovej a Siroisovej (2016). Na druhej strane z našich výsledkov vyplynulo, že Snaha o dokonalost' vykazuje významné pozitívne vzt'ahy s dvoma PERMA prvkami optimálneho prosperovania - so Zaujatím činnost'ou a Úspešným výkonom. Medzi týmito dvoma prvkami vidíme určitú paralelu - oba sú spojené s podobnými psychologickými, kognitívnymi a behaviorálnymi charakteristikami. Zaujatie činnost’ou spočíva v istej schopnosti dosiahnut' stav flow, teda úplné stotožnenie s danou činnost'ou alebo aktivitou, ktorej sa jednotlivec venuje. Práve takéto pohltenie môže súvisiet' s tým, že jednotlivec jednoduchšie dosiahne úspech, ktorý si v danej činnosti stanovil. Je preto možné, že pri zaujatí činnost'ou a rovnako pri dosahovaní úspešného výkonu sa prejavuje snaha alebo potreba mladého človeka konat’ tak, ako najlepšie vie.

Maladaptívna dimenzia Obavy z chýb sa v našom výskume ukázala ako významný negatívny prediktor celkového optimálneho prosperovania a tiež (takmer) všetkých PERMA prvkov, čo je v súlade s viacerými štúdiami (Birch, Riby, \& McGannon, 2019). Výsledky naznačujú, že čím viac sa vysokoškoláci obávajú toho, že sa v konaní dopustia chýb, alebo čím intenzívnejšie premýšl’ajú nad strachom zo zlyhania, tým horšie budú optimálne prosperovat'. Výnimkou bola dimenzia Zaujatia činnost'ou. Seligman (2011) v súvislosti s touto dimenziou poukazuje na úplné odlíšenie flow od pozitívnych emócií, považuje ich za opozitá. Zaujatie činnost'ou si podl'a neho vyžaduje odosobnenie sa od myšlienok a pocitov, aby sa pozornost' mohla sústredit' výlučne na vykonávanú činnost'. Je preto možné, že perfekcionista, ktorý sa obáva chýb, nedokáže byt' natol'ko sústredený a zahíbený do činnosti, ktorú vykonáva, ked'že ho neustále prenasledujú myšlienky o tom, či nezlyhá.

\section{Perfekcionizmus a čas strávený na Instagrame}

D̆alej sme predpokladali, že adaptívny a rovnako aj maladaptívny perfekcionizmus bude pozitívne predikovat’ čas, ktorý strávia vynárajúci sa dospelí na sociálnej sieti Instagram. Naše predpoklady sa nepotvrdili. Zistenia však sú v súlade s výskumom Padoaovej, Beleho a Robertsovej (2018), ktorí zistili, že Na seba orientovaný ani Spoločensky predpísaný perfekcionizmus nebol významne spojený s frekvenciou používania Instagramu. Je možné, že vynárajúci sa dospelí disponujúci určitou úrovňou perfekcionizmu, využívajú svoje perfekcionistické snaženie inou formou ako trávením času na Instagrame. Takouto formou môžu byt' napríklad akademické záujmy, ktoré sú pre väčšinu vysokoškolákov prioritou, najmä v období nášho zberu dát (koniec semestra). Je 
pravdepodobné, že v tejto oblasti sa snažia byt' vysokoškoláci úspešní, preto si v nej stanovujú vysoké štandardy, ktoré si vyžadujú precíznu a dôkladnú prípravu. Takáto príprava môže byt' častokrát časovo náročná, čo môže mat' za následok pokles času, ktorý môžu venovat' sociálnym siet’am. Naše úvahy potvrdzuje aj zistenie Stoebera a Damianovej (2016), že adaptívny aj maladaptívny perfekcionizmus súvisia s workoholizmom a tým aj zníženým množstvom vol'ného času.

\section{Čas strávený na Instagrame a PERMA prvky optimálneho prosperovania}

Výsledky ukázali, že študenti vysokých škôl v našej vzorke trávia na Instagrame v priemere približne 65 minút, pričom štandardná odchýlka bola až 46 minút. Čas strávený na Instagrame sa pritom neukázal ako významný prediktor optimálneho prosperovania u vysokoškolských študentov. Naše zistenia sú tak v rozpore s výsledkami viacerých výskumov, preukazujúcich na negatívne účinky používania Instagramu na psychickú pohodu mladých l'udí a to najmä v oblasti depresie, zníženej sebaúcty, úzkosti a nespokojnosti so svojim telom (Lup, Trub \& Roshenthal, 2015; Sherlock \& Wagstaff, 2019; Fardouly, Willburger \& Vartanian, 2017; Keyte, et al., 2020). Registrujeme však niekol'ko štúdií, ktoré nepotvrdili vzt'ah medzi časom stráveným na Instagrame a životnou spokojnost'ou (Sheldon, \& Bryant, 2016) a depresiou, úzkost'ou či stresom (Padoa, Berle, \& Roberts, 2018).

Vysvetlenie nejednoznačnosti zistení by sme mohli nájst' v obsahu príspevkov a sledovaných profilov na Instagrame. Viacero výskumných, najmä experimentálnych štúdií, preukázalo, že prezeranie ideálnych príspevkov alebo príspevkov celebrít zvyšuje negatívnu náladu a nespokojnost' s vlastným telom (Brown \& Tiggemann, 2016; Tiggeman \& Anderberg, 2019; Prichard, et al., 2020, Chatzopoul, Filieri, \& Dogruyol, 2020) a na druhej strane prezeranie príspevkov, ktoré zobrazujú realitu, zvyšuje spokojnost' so svojim telom (Tiggeman \& Anderberg, 2019; Chatzopoul, Filieri, \& Dogruyol, 2020). Rovnako podstatná sa zdá byt' aj problematika počtu sledovaných cudzích profilov. Ked'že na Instagrame prevažuje trend sledovania tzv. „influencerov“, ktorých používatelia osobne nepoznajú, a ktorých príspevky sú často zidealizované, je pravdepodobné, že ich časté prezeranie môže mat' negatívny dopad na optimálne prosperovanie vynárajúcich sa dospelých. To potvrdzujú aj viaceré štúdie (Lup, Trub, \& Rosenthal, 2015).V našom výskume sme sa pokúšali preskúmat' aj túto oblast', no vzhl'adom na nízku validitu odpovedí sme údaje nepoužili. Považujeme preto za podnetné túto oblast' v budúcnosti preskúmat'.

\section{Limity štúdie}

Predkladaná štúdia má niekol'ko limitov. Okrem spomínaného nezaradenia obsahu sledovaných príspevkov a cudzích profilov, vnímame limity v použitých metodikách a výskumnej vzorke. Vnútorná konzistencia jednotlivých subškál dotazníka PERMA je neuspokojivá, preto pri interpretácii výsledkov kladieme dôraz najmä na celkové skóre dotazníka. Rodovo nevyrovnaná vzorka limitovala analyzovanie rozdielov medzi mužmi a ženami a to najmä v problematike používania sociálnej siete Instagram.

\section{ZÁVER}

Napriek nepotvrdeniu predpokladaného mediačného modelu priniesla predkladaná štúdia viacero významných zistení. Za dôležité považujeme najmä zistenie, že perfekcionizmus ako multidimenzionálny koncept môže pozitívne aj negatívne predikovat' optimálne prosperovanie u vynárajúcich dospelých. Výsledky tiež naznačili, že pre hlbšie pochopenie pôsobenia používania Instagramu na optimálne prosperovanie mladých l'udí je potrebné podrobnejšie analyzovanie množstvo premenných, ktoré do prostredia Instagramu vstupujú (napr. počet sledovaných cudzích profilov, sledovaný obsah, zidealizované príspevky, počet „likeov“ a pod.). 


\section{LITERATÚRA}

Arnett, J. (2000). Emerging adulthood: a theory of development from the late teens through the twenties. American Psychologist, 55(5), 469-480.

Birch. H. A., Riby, L., \& McGann, D. (2019). Perfectionism and PERMA: The Benefits of OtherOriented Perfectionism. International Journal of Wellbeing, 9(1), 20-42.

Brown, Z., \& Tiggemann, M. (2016). Attractive celebrity and peer images on Instagram: effect on Women's mood and body image. Body Image, 19, 37-43.

Butler, J., \& Kern, M. L. (2016). The PERMA-Profiler: A brief multidimensional measure of flourishing. International Journal of Wellbeing, 6(3), 1-48.

Čerešník, M. (2016). Duševná pohoda a prežívanie št’astia. Diagnostické skúsenosti v systéme vyššieho sekundárneho vzdelávania. In E. Gajdošová (Ed.) Škola v kontexte psychológie zdravia a pozitívnej psychológie, Praha, Wolters Kluwer, p. 260-266.

Fardouly, J., Willburger, B. K., \& Vartanian, L. R. (2017). Instagram use and young women's body image concerns and self-objectification: Testing mediational pathways. New Media and Society 20(4), 1390-1395.

Flett, G. L., Hewitt, P. L., Blankstein, K. R., \& Gray, L. (1998). Psychological distress and the frequency of perfectionistic thinking. Journal of Personality and Social Psychology, 75(5), 1363-1381.

Chatzopoulou, E., Filieri, R., \& Dogruyol, S. A. (2020). Instagram and body image: Motivation to conform to the „Instabod“ and consequences on young male wellbeing. Journal of Consumer Affairs, 54(4), 1270-1297.

Keyte, R., Mullis, L., Hussain, M., Cook, A., \& Mantzios, M. (2020). Self-compassion and Instagram use is explained by the relation to anxiety, depression, and stress. Journal of Technology in Behavioral Science, 6, 436-441. https://doi.org/10.1007/s41347-020-00186-z

Kondášová, N. (2017). Perfekcionizmus a emočná inteligencia u jednotlivcov závislých od drog. [Diplomová práca]. Nitra : FSVaZ UKF, 2017. 104 s.

Lup, K., Trub, L., \& Rosenthal, L. (2015). Instagram \#instasad? Exploring associations among Instagram use, depressive symptoms, negative social comparison, and strangers followed. Cyberpsychology, Behavior, and Social Networking, 18(5), 247-252.

Molnar, D. S., \& Sirois, F. M. (2016). Perfectionism, health, \& well-being: Epilogue and future directions. In F. M Sirois, \& D. S. Molnar (Eds.), Perfectionism, Health, and Well-Being (pp. 285-302). New York, NY: Springer.

Padoa, T., Berle, D., \& Roberts, L. (2018). Comparative Social Media Use and the Mental Health of Mothers With High Levels of Perfectionism. Journal of Social and Clinical Psychology, 37(7), 514535.

Perloff, R. M. (2014). Social Media Effects on Young Women's Body Image Concerns: Theoretical Perspectives and an Agenda for Research. Sex roles, 71, 363-377.

Prichard, I., Kavanagh, E., Mulgrew, K., E., Lim., M., S., C., \& Tiggemann, M. (2020). The effect of Instagram \#fitspiration images on young women's mood, body image, and exercise behaviour. Body Image, 33, 1-6.

Seligman, M. (2011). Flourish: A Visionary New Understanding of Happiness and Well-Being. Free Press. 
Sheldon, P., \& Bryant, K. (2016). Instagram: motives for its use and relationship to narcissism and contextual age. Computers in Human Behavior, 58, 89-97.

Sherlock, M., \& Wagstaff, D. L. (2019). Exploring the relationship between frequency of Instagram use, exposure to idealized images, and psychological well-being in women. Psychology of Popular Media Culture, 8(4), 482-490.

Statista (2020). Countries with the most Instagram users 2020. Published by J. Clement, Nov 30, 2020. Dostupné na internete: <https://www.statista.com/statistics/578364/countries-withmost-instagram-users/>

Statista (2021). Slovakia: Instagram users 2018-2020. Published by Joseph Johnson, Jan 5, 2021. Dostupné na internete: <https://www.statista.com/statistics/1024812/instagram-usersslovakia/>

Stoeber J., \& Damian L. (2016) Perfectionism in Employees: Work Engagement, Workaholism, and Burnout. In: Sirois F., Molnar D. (eds) Perfectionism, Health, and Well-Being. p. 265-283. New York: Springer.

Stoeber, J., \& Corr, P. J. (2016). A short empirical note on perfectionism and flourishing. Personality and Individual Differences, 90, 50-53.

Stoeber, J., Kobori, O., \& Tanno, Y. (2010). The Multidimensional Perfectionism Cognitions Inventory-English (MPCI-E): Reliability, validity, and relationships with positive and negative affect. Journal of Personality Assessment, 92(1), 16-25.

Stoeber, J., \& Otto, K. (2006). Positive conceptions of perfectionism: Approaches, evidence, challenges. Personality and Social Psychology Review, 10, 295-319.

Tiggemann, M., \& Anderberg, I. (2019). Social media is not real: The effect of 'Instagram vs reality' images on women's social comparison and body image. New Media \& Society, 22(12), 2193-2199. Turner, P. G., \& Lefevre, C. E. (2017). Instagram use is linked to increased symptoms of orthorexia nervosa. Eating and Weight Disorders-Studies on Anorexia, Bulimia and Obesity, 22(2), 1-8.

\section{PERFECTIONISM, PERMA FLOURISHING AND INSTAGRAM INTENSITY}

Abstract: The aim of the study was to verify the mediation effect of the time spent on Instagram in the relationship between perfectionism and flourishing in emerging adulthood. We also aimed to verify the relationships between tested variables $(1$. perfectionism and flourishing, 2. perfectionism and Instagram intensity, 3. Instagram intensity and flourishing). To measure perfectionism questionnaire MPCI-E (Stoeber, Kobori \& Tano, 2010) was utilized. Time spend on Instagram was measured via activity tracker on Instagram application. Flourishing was measured through the PERMA - Profiler questionnaire (Butler \& Kern, 2016). The research sample consisted of 295 university students aged 18 to 25 years. Results suggested that the perfectionism cognitions dimension of Personal standards positively predicts flourishing, while the perfectionism cognitions dimension of Concern over mistakes predicts flourishing negatively. None of the perfectionism dimensions significantly predict Instagram intensity and Instagram intensity did not predict any of the PERMA flourishing dimensions. From this reason Instagram intensity was not tested as a mediator of the relationship between perfectionism and domains of flourishing.

Key words: perfectionism, flourishing, PERMA, Instagram intensity, emerging adulthood 